\section{FUNDAMENTALS OF CREEP, TESTING METHODS AND DEVELOPMENT OF TEST RIG FOR THE FULL-SCALE CROSSARM: A REVIEW}

\author{
M. R. M. Asyrafa*, M. R. Ishaka,b,c*, M. R. Razmand, M. \\ Chandrasekara
}

aDepartment of Aerospace Engineering, Faculty of Engineering, Universiti Putra Malaysia, 43400 UPM Serdang, Selangor, Malaysia ${ }^{b}$ Aerospace Malaysia Research Centre (AMRC), Faculty of Engineering, Universiti Putra Malaysia, 43400 UPM Serdang Selangor, Malaysia

CLaboratory of Biocomposite Technology (BIOCOMPOSITE), Institute of Tropical Forestry and Forest Products (INTROP), Universiti Putra Malaysia, 43400 UPM Serdang, Selangor, Malaysia

dResearch Centre for Sustainability Science and Governance (SGK), Institute for Environment and Development (LESTARI), Universiti Kebangsaan Malaysia, 43600, UKM Bangi, Selangor, Malaysia
Article history

Received

17 March 2019

Received in revised form

5 May 2019

Accepted

9 May 2019

Published online

25 June 2019

*Corresponding author mohdridzwan@upm.edu.my

\begin{abstract}
Most of transmission line (TL) towers are designed and fabricated in the form of lattice using galvanized steel. The crossarm of the TL is made of Neobalanocarpus or Chengal wood. Recently, it has been reported by an electrical corporation situated in Malaysia that mechanical performance of the wooden crossarm declined below their service life of 40 years due to the extreme tropical weather in Malaysia. At present, composite crossarm made of glass fibre reinforced polymer composite were introduced as substitute in the $132 \mathrm{kV}$ TL tower. However, the research findings lack of information on creep life estimation for the full-scale crossarm. Hence, a new test rig has to be developed to cater the testing operation using the uniaxial tension creep test. The primary objective of this review is to provide an overview of the creep theory and the existing creep testing methodology.
\end{abstract}

Keywords: Creep, uniaxial tension test, test rig, crossarm, transmission line tower

\begin{abstract}
Abstrak
Kebanyakan menara talian penghantaran (TP) direka dan diperbuat dalam bentuk kekisi daripada keluli tergalvani. Lengan silang di menara TP adalah diperbuat daripada kayu Cengal atau Neobalanocarpus. Baru-baru ini, sebuah syarikat elektrik di Malaysia telah menyatakan dalam satu laporan bahawa berlakunya penyusutan prestasi mekanik dari sudut jangka hayat perkhidmatan bagi lengan silang kayu dalam lingkungan 40 tahun yang berpunca daripada cuaca tropika yang melampau di Malaysia. Kini, lengan silang komposit yang diperbuat daripada komposit polimer bertetulang gentian kaca telah diperkenalkan sebagai gantian di Menara TP $132 \mathrm{kV}$. Walau bagaimanapun, penemuan penyelidikan tersebut mempunyai kekurangan maklumat menyeluruh mengenai anggaran jangka hayat rayapan bagi lengan silang tersebut pada skala penuh. Justeru, sebuah rig ujian baru perlu dibangunkan untuk memenuhi operasi ujian dengan menggunakan ujian rayapan ketegangan uniaxial. Objektif utama kajian ini adalah untuk memberikan gambaran keseluruhan bagi teori rayapan dan metodologi pengujian rayapan yang sedia ada.
\end{abstract}

Kata Kunci: Rayapan, ujian ketegangan uniaxial, rig ujian, lengan silang, menara talian penghantaran

(C) 2019 Penerbit UTM Press. All rights reserved 


\subsection{INTRODUCTION}

In the main structure of $275 \mathrm{KV}$ and $132 \mathrm{KV}$ transmission line (TL) tower in Malaysia, wooden crossarms in the form of a cantilever beam are used as supports [1]. Since 1929, a Malaysian electrical transmission company had been using Chengal wood (Neobalanocarpus) for the crossarm in $66 \mathrm{kV}$ transmission tower [2]. The wooden crossarm was chosen due to its extraordinary behaviours in term of mechanical strength and good arc-quenching performance during lightning strikes. Additionally, the Chengal wood also exhibits high natural durability includes soft rot resistance. However, a recent report have shown that the wooden crossarm fails after 24 years. This is due to high temperature and humidity which facilitates the growth of fungi and other destructive microorganisms in the wooden structures [3]. Moreover, natural wood defect of wooden crossarm also tends to cause mechanical failure within the structure $[4,5]$. For all these reasons, the wooden crossarm can only be used for less than 30 years in service. To overcome this issue, a team of researchers have studied on introducing glass fibre reinforced polymer (GFRP) composite crossarm into these towers to replace the wooden members $[6,7]$.

Mechanical failure in these composite cross arms occur due to the buckling, creep, thermal shock and various types of fatigue. In most cases, crossarm structure will experience creep phenomenon more frequently compared to the other factors. Creep occurs when a solid material change in dimensional shape in slow process under constant stress [8]. The process involves a prolonged stress implements below than the material's yield strength. This would cause the material to be deformed with the static loading along the time period [9]. In addition, implementation of higher static loadings and longer time durations will influence the material to be larger deformation subsequently lead to structural failure [10]. Thus, the understanding of creep is crucial in ensuring the longevity of composite crossarm to be in service more than 24 years operation [11].

Various simulations were carried out to examine the creep behaviour of composite crossarm [12, 13]. Experimental works on creep were performed using coupon specimens of composite crossarm material to further understand the material's response and estimate their service life [14-18] However, the behaviour of full scale composite crossarm under the constant load over a long duration has never been attempted. The creep analysis with full scale structure will determine the creep data and information to predict the life expectancy of composite crossarm. In order to evaluate the creep behaviour, a full-scale test rig has to be to developed specifically for actual size composite crossarm used in 132 and $275 \mathrm{kV}$ TL [5].

This review article will focus on gathering literature on various aspects and knowledge of creep principles and experimental procedures which will later be used to develop the rig. More specifically, creep principles, creep testing methodology and current creep testing machines will be discussed.

\subsection{CREEP}

Creep is a tendency of a material to deform permanently under the influence of mechanical stresses owing to the long-term exposure at high levels of stress [19]. Usually, the phenomenon shows changes in size and shape of a material when being exposed to long term loading. In general, creep studies involve the prediction of service life of a structure that is required to withstand a specific constant load in long run [20-22]. The creep studies are divided into two categories such as conventional (time dependent) and accelerated (temperature dependent) method [23].

A material can be perfectly elastic in both the linear and non-linear condition, strain $(\varepsilon)$ is a timeindependent property and is directly related to the applied stress ( $\sigma$ ) [24]. A material which experiences perfectly elastic behaviour such as polymer has the strain directly proportional to the applied stress. It also does store elastic energy during the shape movement and exploit back the energy to revert to their original form when the stress is removed. In addition, when the material is implemented with high temperature, it will perform and act as liquid $[25,26]$. This property is called as viscoelasticity [27-30]. At this point, the deformation becomes time dependent function [31].

Generally, a polymeric material takes thousands of years to deform and relatively is not practical to study the creep by using time dependent method (conventional) [32, 33]. Hence, an appropriate method should be implemented by using heat at elevated temperature in shorter time period. The result from this method can be extrapolated to attain the creep properties within room temperature in longer time period. This experimental work is called as accelerated method or time-temperature superposition model [34].

The use of the time-temperature superposition principle (TTSP) allows the prediction of the material performance beyond the testing time by the construction of the creep master curve. The determination of creep master curve in TTSP model involves plotting the creep strain over time to predict lifespan of structural applications [35]. This is because some materials can remain in service for a prolonged time period and fails suddenly. Nevertheless, the failure analysis can be extrapolated from its behaviour in a shorter time at an elevated temperature as done in master creep analysis [23, 36-38].

\subsection{Stress Relaxation Theory}

Creep usually causes a stress relaxation or extension of a material due to the constant load. Either tensile 
or compression load implemented on a viscoelastic material causes the strain to propagate according to the viscous response [39, 40]. At the same time, the applied stress is slowly declined when the strain of a material is constant. This situation is normally experienced by most of the viscoelastic materials [41]. For instance, a simple viscoelastic beam in the cantilever mode does exhibit tension in the upper part and compression in the lower part due to the applied load [42]. Thus, the existing bending equations can be used to justify the stresses applied and strain movements in a beam. [10,43,44].

Equation 1 can be used to determine the deflection at the end of the beam.

$y=\frac{P L^{3}}{3 E_{e} I}$

Equation 1 can be modified to obtain Equation 2 to calculate static bending modulus of elasticity $\left(E_{e}\right)$.

$y=\frac{P L^{3}}{3 E_{e} I}=\frac{4 P L^{3}}{3 E_{e} b h^{3}} \rightarrow$ rearranged $\rightarrow E_{e}=\frac{4 P_{\max } L^{3}}{y b h^{3}}$

Where; $y$ is the end deflection $(m), E_{e}$ is the bending modulus of elasticity (N/m2), $P$ is the endpoint load (N), $P_{\max }$ is the maximum load, $L$ is the cantilever beam length $(\mathrm{m}), \mathrm{I}$ is the area moment of inertia $\left(\mathrm{m}^{4}\right), b$ is the base width of the specimen (m), and $h$ is the thickness of the specimen (m).

Equation 3 can be used to formulate the maximum bending stress at a known deflection [45].

$\sigma_{\text {ave }}=\frac{3 P(L)}{b h^{2}}$

Equation 4 is implemented to formulate the total strain experienced by the system.

$\mathcal{E}_{T}=\frac{\sigma_{\text {ave }}}{E_{e}}=\left[\frac{\left(\frac{3 P(L)}{b h^{2}}\right)}{\left(\frac{4 P_{\max } L^{3}}{y b h^{3}}\right)}\right]$

A research conducted by Hunt et al. (2015) implements stress relaxation procedure to study the orientation of bending of a beam subsequently to analyse their creep behaviour [10]. The authors applied bending load on vertical beam specimens and recorded its changes in deformation. The test device was divided into two parts: mechanical structure and data processing. The changes of the displacement happened at the beam end are logged by laser displacement gauge which connects directly to computer. The results showed that the cantilever beam test has high potential to characterize of material properties during relaxation as different composite materials have different stress relaxation. Figure 1 shows component diagram of the vertical cantilever beam test used by the authors.

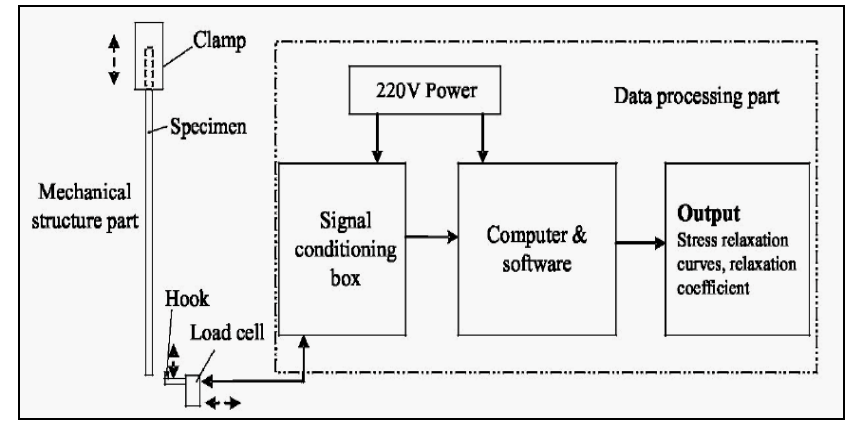

Figure 1 Schematic cantilever beam testing rig [10]

\subsection{CREEP TESTING}

Creep testing is an experimental method that was conducted using material tester via controlling speed to observe and analyze measuring deformation over time. The test procedure is used to identify creep properties of a specimen subjected to either a tensile or compressive load at constant temperature applied for long period of time. During the test, deformation rate of sample material at a constant temperature over the applied stress is determined as creep rate. Creep increases with temperature and it is more common when a material is exposed to high temperatures for a long time or at the melting point of the material. Thus, a graph of creep versus time can be obtained for further analysis. Creep studies at elevated temperature is performed in an environmental chamber for precise heating and cooling control. The process of regulatory temperature is very critical to minimize the effect of thermal expansion on the sample tested [46, 47].

In general, creep can be divided into three main stages which clarify more about the creep behaviour (Figure 2(a) \& (b)). Firstly, the primary creep occurs at a rapid rate and slows down with the time. Next, the secondary creep has constant rate restively as the time continues to run. Finally, tertiary creep occurs where the creep rate accelerates until the material breaks or rupture. It is also common to measure creep recovery. Creep recovery test will determine the stress-relaxation which is the rate of decrease in deformation that takes place when the load is removed. In this case, creep test is referred to as stress-relaxation testing [48]. 


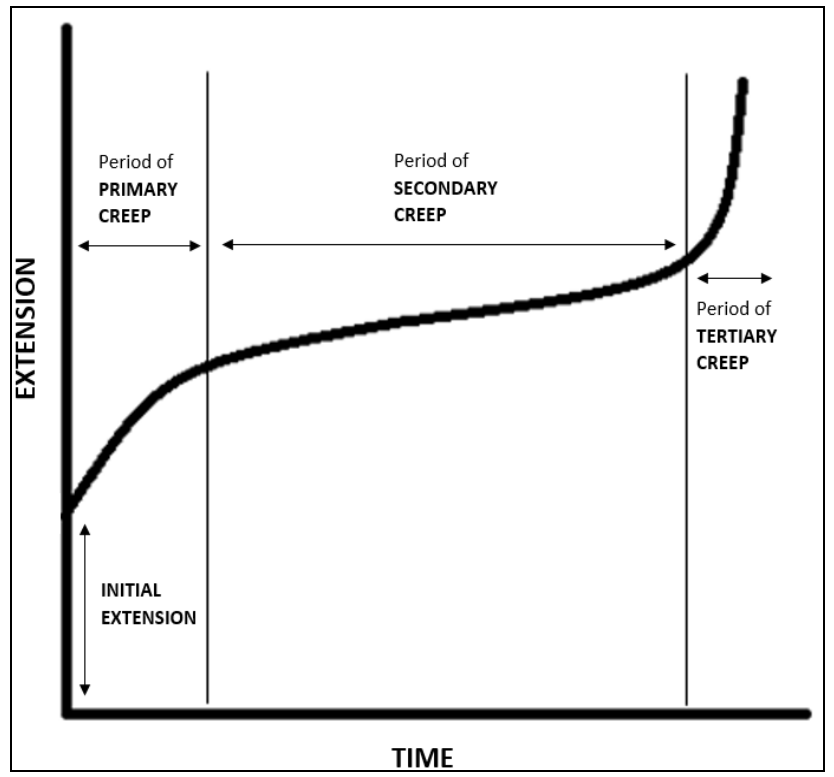

Figure 2 Typical graph of creep in defined extension

A linear graph denotes that the material under stress is gradually deforming and this would be harder to track at what level of stress the material can handle. This would also mean that the material would not have distinct stages, which would make the breaking point of a material less predictable [19, 49].

\subsection{CONVENTIONAL METHOD}

Creep behaviour of a material can be studied using conventional method that requires minimum testing hours about 10, 000 hours to produce data in ambient condition. To have a complete analysis of this test method, the acquired data has to be extrapolated linearly to predict long-term behavior within one log cycle [50]. On top of that, the uncertainty of the extrapolation expands along the time period. The test is the most reliable to assess the creep condition within the testing period even though it cannot forecast long-term creep condition more than test duration.

Hence, Equation 5 which is creep can be formulated as its inverse of stiffness in a timedependent function:

$S(t)=\frac{\varepsilon(t)}{\sigma}$

Where $S(t)$ is creep compliance, $\varepsilon(t)$ is strain with time dependent and $\sigma$ is applied stress.

Studies by Slocumb et al. (1986) and Lawrence (1987) on the geosynthetic such as high density polyethylene (HDPE) geonets by applying compressive force at constant load for 103 hours. The data was then extrapolated to identify the creep reduction factor at 104 hours [51, 52]. In another study, the compressive creep behaviour of different geocomposites were evaluated using the conventional creep test for 500 hours under the combined normal and shear stresses [53]. The limitation of using the conventional method is that the estimated creep value was shorter than the service life of the HDPE geonet.

\subsection{Accelerated Method}

In the accelerated creep method, a timetemperature Superposition model (TTSP) is generated within a short period of time at elevated temperature followed by a master curve. A shift parameter $\left(a_{t}\right)$ is defined to address the creep behaviour at a referred temperature $[33,49,54]$. Based on the TTSP principle, the dynamic property in frequency function at a reference temperature $\left(T_{r}\right)$ is similar in shape to the same function in neighbouring temperature. Hence, $S(t)$ against the logarithmic response of time at exact temperature can be horizontally shifted along the reduced time axis and made to overlap at the other neighbouring temperatures. This shift distance along the reduced time axis is called the shift factor $\left(a_{t}\right)$ [28] and is given as in the Equation 6:

$a_{T}=\frac{t}{t_{r}}$

Here, $t$ is time step for the specific temperature while $t_{r}$ is the reduced time in response to references temperature [55].

\subsection{CREEP TESTING MACHINE}

A device that measures the alteration of a material after it has been put through different forms of constant stress are called as a creep- testing machine. The machine is vital for the understanding on the strain of an object under pressure. The machine helps in producing a creep timedependent curve by analysing the steady state of creep by referring to the time it takes for material change. The main functions of creep machines are to determine the stability of the material and its behaviour when the stress acts on it [56-58].

The design of the machine is based on the understanding of the process metallurgy, physical and mechanical properties of a metal. The common creep testing machine mostly used for a constant load creep testing machine. The constant load creep machine consists of a loading platform, foundation, fixture devices, and furnace. The fixture devices are the grips and pull rods [21, 59]. For starting, the basic design of the creep testing machine is loading platform, dial gauge, grips and heating chamber as follows [60-63]: 
- Load plafform or sometimes called load hanger is where the object will endure pressure at a constant rate.

- Grips/fittings are used to hold the material tested in a certain position. A position is important because if the alignment is off, the machine will deliver inaccurate readings of the creep of the material.

- Strain measurement instrument is used to measure the strain. It is the device that captures the movement of the object in the machine. The load beam transfers the movement from the grip to the dial gauge.

- Heating Chamber is what surrounds the object and maintain the temperature that the object is subjected to.

In this section, the creep testing machines developed by the researchers were discussed. According to Brunbauer (2010), the testing machine for compression creep tests on polymer at elevated temperature was developed based on variation temperature from $25^{\circ} \mathrm{C}$ to $200^{\circ} \mathrm{C}$ [64]. Thus, a method for a proper load application is needed, that allows to load and unload the specimen in a controlled and flexible way also at elevated temperature. An aluminium piston is gliding inside a cylinder. The piston is acted to regulate the speed of tensile action on the sample used. For the chosen specimen type with a diameter of $10 \mathrm{~mm}, 1960 \mathrm{~N}$ is required to reach a stress of $25 \mathrm{MPa}$. The controlled handling of the weights, also at higher temperatures and the limited space in the furnace. A schematic overview of tensile creep testing setup is depicted in Figure 3.

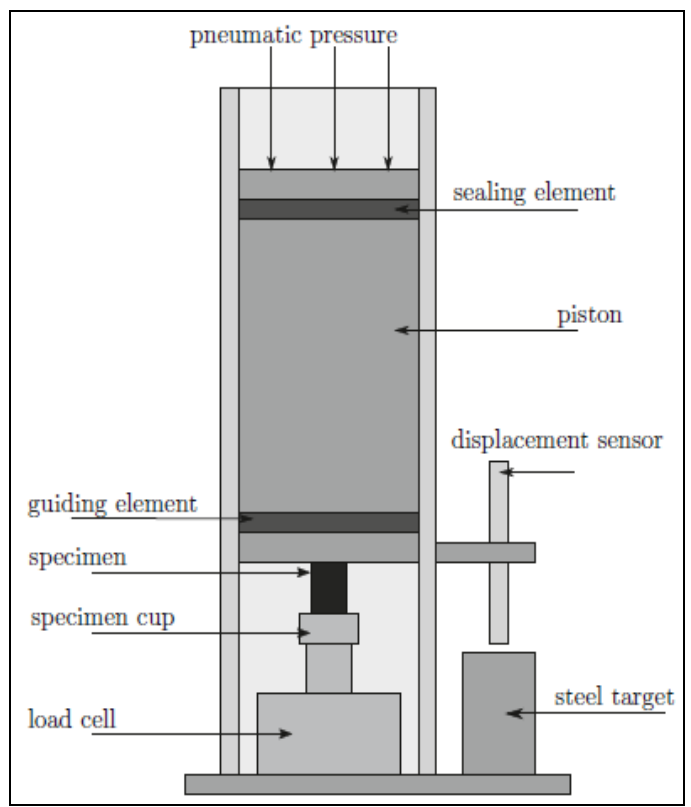

Figure 3 Schematic of tensile creep testing rig [15]

According to Loni (2013), the study was conducted to explore the validity of the Time-Temperature-Stress Superposition Principle (TTSSP) to describe the creep behaviour of glass fibre reinforced polymer (GFRP) pultruded beams which include both short and longterm creep tests $[15,65]$. The results show the extent of validity of the TTSSP helps to predict the creep behaviour of GFRP composites. In this case, the material specifications and the duration of the test is specified to the machine. These tests have been carried out using a 4-point bending scheme (Figure 4), where two vertical loads $F$ are applied at the thirds of the $600 \mathrm{~mm}$ total span. The experimental setup was designed according to the European Standard EN ISO 14125:1988 [66]. The test is conducted based on specific custom-made apparatus (Figure 5). The metallic frame of the apparatus is made of standard steel U-profiles. The support of the specimens is made of cylindrical tubes of $48 \mathrm{~mm}$ diameter. Twelve experiments can be simultaneously tested in the apparatus. The span of the specimens may be either $600 \mathrm{~mm}$ or $800 \mathrm{~mm}$. The load is applied through levers which allow multiplying the applied weight by a factor of 7.

As indicated by Hui Peng et al. (2017), the creep analysis method was conducted on a dynamic mechanical analyser (DMA 2980, TA Instrument) via a sample chamber in dry air with a tensile clamp with the midpoint distance of $17 \mathrm{~mm}$ as shown in Figure 6 [36]. The specimens were subjected to isothermal creep segments for 20 min at each $10^{\circ} \mathrm{C}$ interval in a temperature range from 30 to $150{ }^{\circ} \mathrm{C}$, and $20 \mathrm{~min}$ equilibration/recovery periods were inserted between creep segments. 


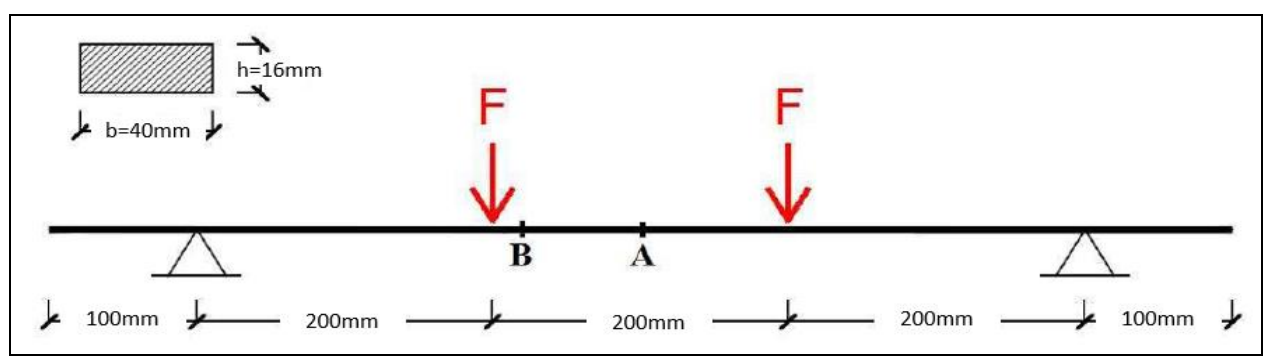

Figure 4 Schematic representation of the experimental setup for creep bending testing apparatus [65]

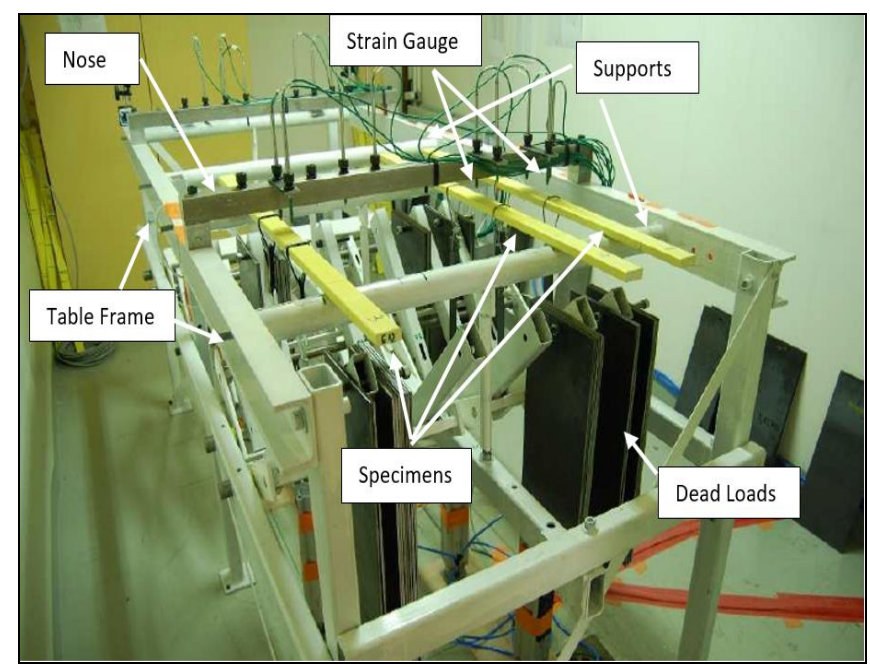

Figure 5 Current creep testing apparatus [65]

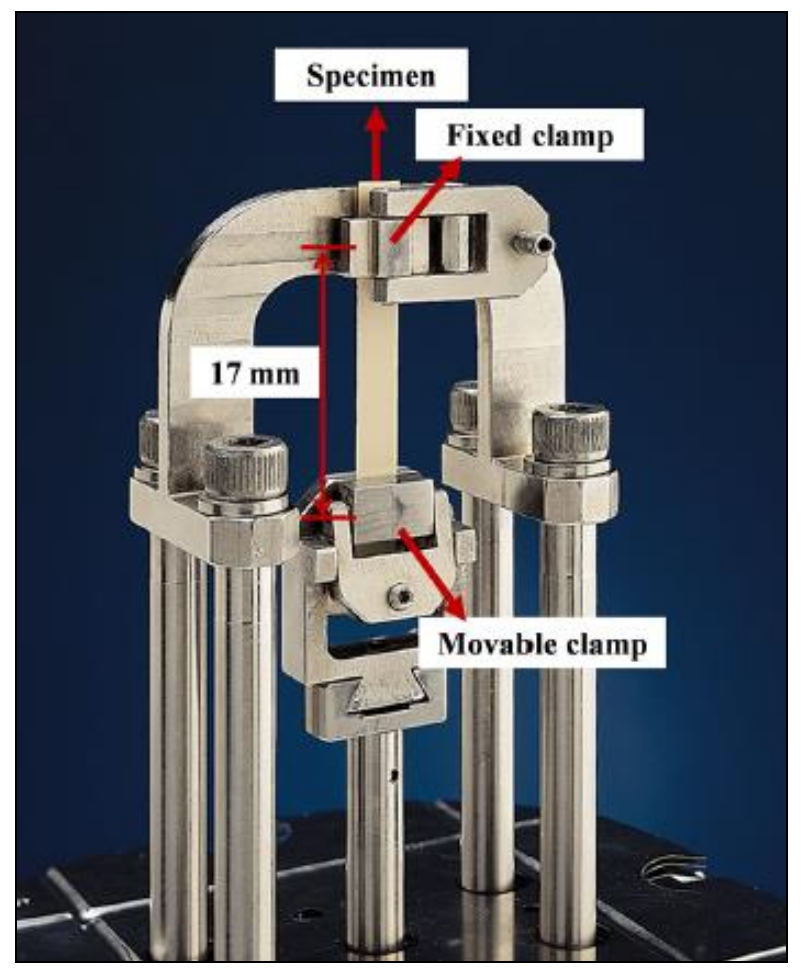

Figure 6 Creep tensile testing rig [36]
An exploratory study conducted by Segovia et al. (2013) had established a finding on mechanical behaviour of sugar maple (Acer saccharum Marsh.) wood using creep tests in cantilever beam mode. The test was carried out in controlled environment chamber which is maintained at constant temperature of $30 \pm 0.5^{\circ} \mathrm{C}$ in both constant and variable environments. For a constant environment, relative humidity is maintained at 37,67 and $83 \%$ while the variable condition is specifically within the range of 37 to $83 \%$. The specimens were fabricated in radial position and cut into $110 \times 25 \times 7 \mathrm{~mm}$ of dimensions. The experimental conditions for the test were summarized in the Table 1. The set up specimens in the test apparatus were designed by implementing the cantilever beam mode to conduct the mechanical test. A metal structure was installed firmly at the end of the specimens to hold the specimen and a dead load was applied at another end. A linear variable differential transformer (LVDT) was used to measure deflection at the free end of specimen. The LVDT and the wet and dry thermocouples were connected to a data acquisition system (Stress Analysis Data System 5000) which allowed for recording the readings every minute and monitoring the data in real time. Normally, the LVDT was located at $70 \mathrm{~mm}$ from the metal jaw holding the other end of the specimen as it was effective distance. In addition, the load application point was fixed at $5 \mathrm{~mm}$ away from the LVDT. Hence, the $75 \mathrm{~mm}$ away from the metal jaw and $5 \mathrm{~mm}$ away from the free end of the specimen as shown in Figure 7 [20].

In general, the current creep testing possesses several methods which are distinguished by its applications as shown in Table 1.

It can be observed from the above discussions that the creep testing machines for specimens to be tested under the bending, compression and tensile loads have been developed by researchers according to the usage of materials in particular application and test environment. Since the composite crossarm used in TL are cantilever beam structures, the uniaxial creep tension test is the most suitable method to estimate the service life under creep. The methodology and literature related to the uniaxial tension creep test is discussed below. 
Table 1 Summary of current creep testing machine $[15,20,36,64-66]$

\begin{tabular}{|c|c|c|c|c|c|c|}
\hline Testing mode & Components & Testing method & $\begin{array}{c}\text { Specimen } \\
\text { size }\end{array}$ & Instrumentation & Loading sources & Output Results \\
\hline Compression & $\begin{array}{l}\text { Piston, load } \\
\text { cell, guiding } \\
\text { and sealing } \\
\text { element }\end{array}$ & $\begin{array}{l}\text { Accelerated } \\
\text { and } \\
\text { conventional }\end{array}$ & Coupon & Complex & $\begin{array}{c}\text { Depends on the } \\
\text { extensor speed } \\
\text { powered by } \\
\text { electricity }\end{array}$ & $\begin{array}{c}\text { Not } \\
\text { representative } \\
\text { as whole } \\
\text { structure }\end{array}$ \\
\hline Tensile & $\begin{array}{l}\text { Fixed and } \\
\text { movable } \\
\text { clamp }\end{array}$ & $\begin{array}{l}\text { Accelerated } \\
\text { and } \\
\text { conventional }\end{array}$ & Coupon & Complex & $\begin{array}{c}\text { Depends on the } \\
\text { extensor speed } \\
\text { powered by } \\
\text { electricity }\end{array}$ & $\begin{array}{c}\text { Not } \\
\text { representative } \\
\text { as whole } \\
\text { structure }\end{array}$ \\
\hline Bending & $\begin{array}{c}\text { Nose, support } \\
\text { span, dead } \\
\text { loads }\end{array}$ & $\begin{array}{l}\text { Accelerated } \\
\text { and } \\
\text { conventional }\end{array}$ & Coupon & Simple & $\begin{array}{l}\text { Depends on } \\
\text { dead loadings }\end{array}$ & $\begin{array}{c}\text { Not } \\
\text { representative } \\
\text { as whole } \\
\text { structure }\end{array}$ \\
\hline $\begin{array}{l}\text { Uniaxial } \\
\text { Tension }\end{array}$ & $\begin{array}{l}\text { Load } \\
\text { cell/dead } \\
\text { loads, fixed } \\
\text { clamp, hook }\end{array}$ & Conventional & $\begin{array}{l}\text { Full scale } \\
\text { structure/ } \\
\text { Coupon }\end{array}$ & Simple & $\begin{array}{l}\text { Depends on } \\
\text { dead loadings }\end{array}$ & $\begin{array}{c}\text { Reliable } \\
\text { structural data }\end{array}$ \\
\hline
\end{tabular}

\subsection{Uniaxial Creep Tension Mechanism}

The creep test of metals usually takes a long period of time even usually it is shorter in period than the service life of actual structure which the test is being conducted. Hence, the calculations and the analysis to acquire creep data and behaviour is vital in describing the behaviour pattern of materials. The tests will provide adequate information and scientific data in the interpretation of deformation of test specimens as a function time [67-70]. During the creep tensile test, one end is fixed and the free end of the specimen is subjected to constant tension load at a constant temperature. The creep rate will be recorded with respect of time [70-75]. Figure 7 depicted the schematic overview long term test of uniaxial creep tension test [70].

The study Van Mier and Van Vliet shows an overview of uniaxial tension test methods on quasibrittle materials [76]. The diversity in those materials leads to numerous problems such as the necessity of large specimens and the development of secondary flexural moments, causing redistribution of stresses. In another study, a group of researcher led by Plizzari used uniaxial tension tests in order to explore the behavior of Steel Fibre Reinforced Concretes (SFRCs) under cyclic loads [77]. According to Li et al. (1998), a study was established to prove the uniaxial behavior of SFRC and Macro Synthetic Fibre Reinforced Concrete (MSFRC) specimens with fibre volume fractions from 2 to $6 \%$ [78].

The creep test can be conducted in various stiffness setup to study the strain movement of a material. According to Barragán et al. (2001) and Zerbino et al. (2016), a parametric study was carried out on specimens containing steel fibres and analyzed the effects of various parameters including the depth of the notch and the slenderness of the cylinders $[79,80]$.

The creep test should be performed according to the respective ASTM standards. The requirements in conducting tension creep test are as follows [81, 82]:
- ASTM E 21-66T explains short time elevated temperature tension tests of materials. It is applicable to metals which are highly resistant to creep and which are to be used at moderately high temperatures but which are lower than the equi-cohesive temperatures for those metals and, yet, where strength characteristics as well as creep characteristics, are important.

- ASTM e 151-64 clarifies tension tests of metallic materials at elevated temperatures with rapid heating and conventional or rapid strain rates.

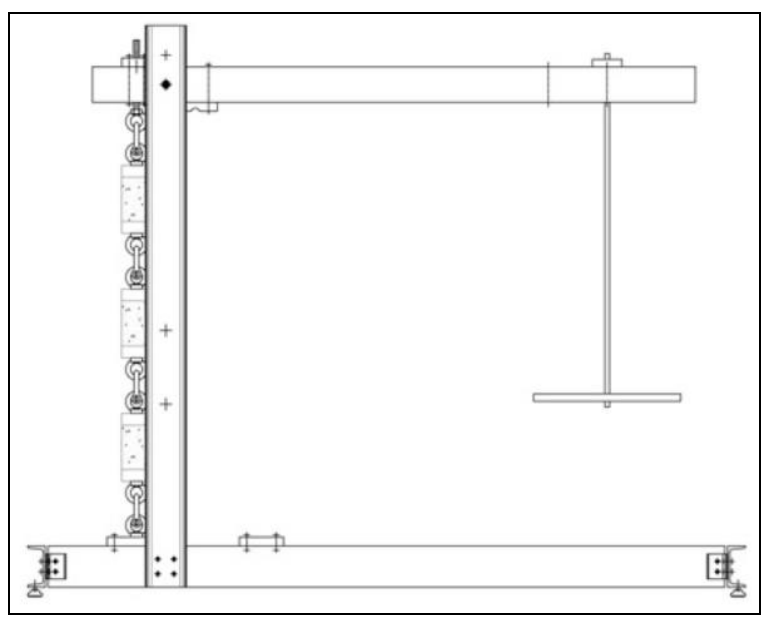

Figure 7 Experimental setup for long-term uniaxial tensile test [70] 


\subsection{CONCLUSION}

The enhancement of creep studies from coupon specimens to full scale size of crossarm are the paradigms to further understand the life expectancy of the structure operating in actual conditions. Previous studies highlight that creep testing machines were developed specifically to replicate the loading and environmental conditions, the material is supposed to undergo during their service life. In similar way, for the full-scale composite cross arm, a test rig which can facilitate the uniaxial tensile creep test in the cantilever mode has to be developed. To ensure reliability of the collected data, the test rig should comply with the current creep testing machine which helps in describing these aspects. Results from this test will help to predict the service more accurately.

To conclude, the creep testing of coupon specimens is widely covered using both conventional and accelerated methods. However, creep studies on the full-scale structures are limited and especially for the crossarm structures, hardly the full-scale study has been attempted. Additionally, the uniaxial creep tension mechanism specifically cantilever beam mode of creep testing would be the most suitable testing operation in finding the creep life of crossarm for long term loadings. Moreover, the stress relaxation theory can be implemented to predict the service life of the tested full scale structure. In addition, the creep testing rig should have loading platform, strain measurement instrument, fittings and heat chamber (if conducted in TTSP mode). The test has to be performed according to the international standards such as ASTM E21 and ASTM E151 to ensure acceptance from the industries.

\section{Acknowledgement}

The authors would like to thank Universiti Putra Malaysia (UPM) for the financial support through Geran Putra, UPM with VOT no. 9634000. The authors are very thankful to Department of Aerospace Engineering, Faculty of Engineering, UPM for providing facilities to conduct computational simulation modelling and analysis.

\section{References}

[1] Khalid, K., Kean, L. S., Cheong, N. K., Sahri, H., and Aziz, S. A. 2004. Development of Ultrasonic and Microwave Techniques for Detection of Decay in Wooden Cross-arms. 116th WCNDT 2004 - World Conf. NDT. Montreal, Canada. $2-4$.

[2] Liew, A. C. 1993. Assessment of the Lightning Performance of Quadruple Circuit Transmission Lines with Steel and Wooden Crossarms. Electr Power Syst Res. 27(2): 91-97.

[3] Khalid, K., Sahri, M. H., Ng, K. K., and Fuad, S. A. 2001. Microwave Reflection Technique for Determination of Density, Moisture and Stage of Decay in Wood. Proc. 4th
Int. Conf. EM Wave Interact. with Water Moist Subst. Weimar Germany. 79-87

[4] Nikhil, T., Chandrahas, T., Chaitanya, C., Sagar, I., and Sabareesh, G. R. 2016. Design and Development of a TestRig for Determining Vibration Characteristics of a Beam. Procedia Eng. 144: 312-320.

DOI: http://dx.doi.org/10.1016/j.proeng.2016.05.138.

[5] Berk, R. W. 2000. Tenaga Nasional Berhad Transmission Line Design Manual. Tennessee: Goodlettsville Inc.

[6] Selvaraj, M., Kulkarni, S. M., and Rameshbabu, R. 2014. Performance Analysis of an Overhead Power Transmission Line Tower Using Polymer Composite Material. Procedia Mater Sci. 5: 1340-1348.

DOI: http://dx.doi.org/10.1016/j.mspro.2014.07.451.

[7] Yeh, H. Y., and Yang, S. C. 1997. Building of a Composite Transmission Tower. J Reinf Plast Compos. 16(5): 414-424. DOI: http://dx.doi.org/10.1177/073168449701600502.

[8] Moutee, M., Fafard, M., Fortin, Y., and Laghdir, A. 2005. Modeling the Creep Behavior of Wood Cantilever Loaded at Free End During Drying. Wood Fiber Sci. 37(3): 521-534.

[9] Zhang, Z., Yang, J. L., and Friedrich, K. 2004. Creep Resistant Polymeric Nanocomposites. Polymer (Guildf). 45(10): 3481-3485. DOI: http://dx.doi.org/10.1016/j.polymer.2004.03.004.

[10] Hunt, J. F., Zhang, H., and Huang, Y. 2015. Analysis of Cantilever-beam Bending Stress Relaxation Properties of Thin Wood Composites. BioResources. 10(2): 3131-3145. DOI: http://dx.doi.org/10.15376/biores.10.2.3131-3145.

[11] Engineering Department of TNB Transmission Division. 2013. Investigation Report on Wooden Crossarm Failure at 132 KV KKSRPPAN L2.

[12] Magimay, F. 1977. Lightning Performance of N.E.B.'s 275 kV Transmission Line. J Inst Eng Malaysia. 23: 45-54.

[13] Selvaraj, M., Kulkarni, S., and Babu, R. R. 2013. Analysis and Experimental Testing of a Built-up Composite Cross Arm in a Transmission Line Tower for Mechanical Performance. Compos Struct. 96: 1-7.

DOI: http://dx.doi.org/10.1016/j.compstruct.2012.10.013.

[14] Chang, F. C., Lam, F., and Kadla, J. F. 2013. Using Master Curves Based on Time-temperature Superposition Principle to Predict Creep Strains of Wood-Plastic Composites. Wood Sci Technol. 47(3): 571-584. DOI: http://dx.doi.org/10.1007/s00226-012-0518-3.

[15] Loni, S., Stefanou, I., and Valvo, P. S. 2013. Experimental Study on the Creep Behavior of GFRP Pultruded Beams. AIMETA 2013--XXI Congr. Naz. dell Associazione Ital. di Mecc. Teor. e Appl. 1-10

[16] Jaafar, C. N. A., Rizal, M. A. M., and Zainol, I. 2018. Effect of Kenaf Alkalization Treatment on Morphological and Mechanical Properties of Epoxy/Silica/Kenaf Composite. Int J Eng Technol. 7: 258-263. DOI: $\mathrm{http}: / / d x . d o i . o r g / 10.14419 / \mathrm{ijet.v7i4.35.22743.}$

[17] Jaafar, C. N. A., Zainol, I., and Rizal, M. A. M. 2018. Preparation and Characterisation of Epoxy/Silica/Kenaf Composite using Hand Lay-up Method. 27th Sci. Conf. Microsc. Soc. Malaysia (27th SCMSM 2018). Melaka, Malaysia. 2-6.

[18] Ashraf, W., Ishak, M. R., Zuhri, M. Y. M., Yidris, N., Yaacob, A. M. B., and Asyraf, M. R. M. 2019. Investigation of Different Facesheet Materials on Compression Properties of Honeycomb Sandwich Composite. Semin. Enau Kebangs. Bahau, Negeri Sembilan, Malaysia. 129-132.

[19] Kaboorani, A., Blanchet, P., and Laghdir, A. 2013. A Rapid Method to Assess Viscoelastic and Mechanosorptive Creep in Wood. Wood Fiber Sci. 45(4): 1-13.

[20] Segovia, F., Blanchet, P., Laghdir, A., and Cloutier, A. 2013. Mechanical Behaviour of Sugar Maple in Cantilever Bending under Constant and Variable Relative Humidity Conditions. Int Wood Prod J. 4(4): 225-231.

DOI: http://dx.doi.org/10.1179/2042645312y.0000000024.

[21] Mancusi, G., Spadea, S., and Berardi, V. P. 2013. Experimental Analysis on the Time-dependent Bonding of FRP Laminates under Sustained Loads. Compos Part B Eng. 46: 116-122. 
DOI: http://dx.doi.org/10.1016/j.compositesb.2012.10.007.

[22] Pérez, C. J., Alvarez, V. A., and Vázquez, A. 2008. Creep Behaviour of Layered Silicate/Starch-Polycaprolactone Blends Nanocomposites. Mater Sci Eng A. 480(1-2): 259265. DOI: http://dx.doi.org/10.1016/j.msea.2007.07.031.

[23] Anand, A., Banerjee, P., Prusty, R. K., and Chandra Ray, B. 2018. Lifetime Prediction of Nano-silica based Glass Fibre/Epoxy composite by Time Temperature Superposition Principle. IOP Conf Ser Mater Sci Eng. DOI: http://dx.doi.org/10.1088/1757-899X/338/1/012020.

[24] Kumar Ghosh, S., Prusty, R. K., Rathore, D. K., and Ray, B. C. 2017. Creep Behaviour of Graphite Oxide Nanoplates Embedded Glass Fiber/Epoxy Composites: Emphasizing the Role of Temperature and Stress. Compos Part A Appl Sci Manuf. 102: 166-177. DOl: http://dx.doi.org/10.1016/j.compositesa.2017.08.001.

[25] Sun, N., and Frazier, C. E. 2007. Time/temperature Equivalence in the Dry Wood Creep Response. Holzforschung. 61 (6): 702-706. DOI: http://dx.doi.org/10.1515/HF.2007.114.

[26] Taniguchi, Y., Ando, K., and Yamamoto, H. 2010 Determination of Three-dimensional Viscoelastic Compliance in Wood by Tensile Creep Test. J Wood Sci. 56(1): 82-84

DOI: http://dx.doi.org/10.1007/s10086-009-1069-6.

[27] Cyras, V. P., Martucci, J. F., lannace, S., and Vazquez, A. 2002. Influence of the Fiber Content and the Processing Conditions on the Flexural Creep Behavior of Sisal-PCLstarch Composites. J Thermoplast Compos Mater. 15(3): 253-265. DOI: http://dx.doi.org/10.1177/0892705702015003454

[28] Sá, M. F., Gomes, A. M., Correia, J. R., and Silvestre, N. 2011. Creep Behavior of Pultruded GFRP Elements - Part 1: Literature Review and Experimental Study. Compos Struct. 93(10): 2450-2459.

DOl: http://dx.doi.org/10.1016/j.compstruct.2011.04.013.

[29] Hao, A., Chen, Y., and Chen, J. Y. 2014. Creep and Recovery Behavior of Kenaf/polypropylene Nonwoven Composites. J Appl Polym Sci. 131 (17): 8864-8874. DOI: http://dx.doi.org/10.1002/app.40726.

[30] Izer, A., and Bárány, T. 2010. Effect of Consolidation on the Flexural Creep Behaviour of All-polypropylene Composite. Express Polym Lett. 4(4): 210-216.

DOI: http://dx.doi.org/10.3144/expresspolymlett.2010.27.

[31] Hyde, T. H., and Sun, W. 2009. A Novel, High-sensitivity, Small Specimen Creep Test. J Strain Anal Eng Des. 44(3): 171-185. DOI: http://dx.doi.org/10.1243/03093247JSA502.

[32] Lim, B. S., Lee, S. Y., Yang, H. S., Kim, H. J., Jeong, C. S., and Lee, J. N. 2004. Creep Behavior and Manufacturing Parameters of Wood Flour Filled Polypropylene Composites. Compos Struct. 65(3-4): 459-469.

DOI: http://dx.doi.org/10.1016/j.compstruct.2003.12.007.

[33] Ponsot, B., Valentin, D., and Bunsell, A. R. 1989. The Effects of Time, Temperature and Stress on the Long-term Behaviour of CFRP. Compos Sci Technol. 35(1): 75-94. DOI: http://dx.doi.org/10.1016/0266-3538(89)90071-7.

[34] Bueno, B. S., Costanzi, M. A., and Zornberg, J. G. 2005. Conventional and Accelerated Creep Tests on Nonwoven Needle-punched Geotextiles. Geosynth Int. 12(6): 276-287. DOI: http://dx.doi.org/10.1680/gein.2005.12.6.276.

[35] Hadid, M., Guerira, B., Bahri, M., and Zouani, K. 2014. The Creep Master Curve Construction for the Polyamide 6 by the Stepped Isostress Method. Mater Res Innov. 18(sup6): S6-336-S6-339.

DOl:http://dx.doi.org/10.1179/1432891714z.0000000001022

[36] Peng, H., Jiang, J., Lu, J., and Cao, J. 2017. Application of Time-temperature Superposition Principle to Chinese fir Orthotropic Creep. J Wood Sci. 63(5): 455-463. DOI: http://dx.doi.org/10.1007/s10086-017-1635-2.

[37] Alvarez, V. A., Kenny, J. M., and Vázquez, A. 2004. Creep Behavior of Biocomposites Based on Sisal Fiber Reinforced
Cellulose Derivatives/Starch Blends. Polym Compos. 25(3): 280-288. DOI: http://dx.doi.org/10.1002/pc.20022.

[38] Zhu, S. P., and Huang, H. Z. 2010. A Generalized Frequency Separation-strain Energy Damage Function Model for Low Cycle Fatigue-creep Life Prediction. Fatigue Fract Eng Mater Struct. 33(4): 227-237.

[39] Bernstein, B., Kearsley, E. A., and Zapas, L. J. 1963. A Study of Stress Relaxation with Finite Strain. Trans Soc Rheol. 7(1): 391-410.

[40] Zhuang, W. Z., and Halford, G. R. 2001. Investigation of Residual Stress Relaxation under Cyclic Load. Int J Fatigue. 23: 31-37.

[41] Schwarzl, F., and Staverman, A. J. 1952. Time-temperature Dependence of Linear Viscoelastic Behavior. J Appl Phys. 23(8): 838-843.

[42] Zhuang, F. K., Tu, S. T., Zhou, G. Y., and Wang, Q. Q. 2015. A Small Cantilever Beam Test for Determination of Creep Properties of Materials. Fatigue Fract Eng Mater Struct. 38: 257-267. DOI: http://dx.doi.org/10.1111/ffe.12225.

[43] Feng, S. H., and Zhao, Y. K. 2010. The Summary of Wood Stress Relaxation Properties and Its Influencing Factors. WoodProc Mach. 25(3): 39-40.

[44] Whitney, J. M., Browning, C. E., and Hoogsteden, W. 1982. A Double Cantilever Beam Test for Characterizing Mode Delamination of Composite Materials. J Reinf Plast Compos. 1 (4): 297-313.

[45] Liu, H. W. 2004. Mechanics of Materials. Beijing: China Machine Press

[46] Ma, X., Jiang, Z., Tong, L., Wmang, G., and Cheng, $H$. 2015. Development of Creep Models for Glued Laminated Bamboo Using the Time-temperature Superposition Principle. Wood Fiber Sci. 47(2): 1-6.

[47] Chang, E., and Dover, W. D. 2001. Characteristic Parameters for Stress Distribution along the Intersection of Tubular Y, T, X and DT Joints. J Strain Anal Eng Des. 36(3): 323-339.

DOI: http://dx.doi.org/10.1243/0309324011514502.

[48] Findley, W. N. 1944. Creep Characteristics of Plastics. Symp Plast ASTM. 118-134.

[49] Narayana, V. J. S., Balasubramaniam, K., and Prakash, R. V. 2010. Detection and Prediction of Creep-damage of Copper Using Nonlinear Acoustic Techniques. AIP Conf Proc. 1211: 1410-1417.

DOI: http://dx.doi.org/10.1063/1.3362233

[50] Gamalath, S. S. 1991. Long Term Creep Modelling of Wood Using Time Temperature Superposition Principle. Virginia Polytechnic Institute and State University

[51] Slocumb, R. C. Demeny, D. D. and Christopher, B. R. 1986. Creep Characteristics of Drainage Nets. Proc. 9th Annu. Madison Waste Conf. 658-671.

[52] Lawrence, C. A. 1987. Selected Design Considerations for a Synthetic Landfill or Waste Impoundment. Drexel University, Philadelphia, USA.

[53] Jarousseau, C. and Gallo, R. 2004. Drainage Geocomposites: Relation between Water Flow Capacity and Thickness in the Long Term. Proc. 3rd EuroGeo Conf. 349-354

[54] Tajvidi, M., Falk, R. H., and Hermanson, J. C. 2005. Timetemperature Superposition Principle Applied to a KenafFiber/High-density Polyethylene Composite. J Appl Polym Sci. 97(5): 1995-2004. DOI: http://dx.doi.org/10.1002/app.21648.

[55] Li, R. 2000. Time-temperature Superposition Method for Glass Transition Temperature of Plastic Materials. Mater Sci Eng A. 278(1-2): 36-45. DOI: http://dx.doi.org/10.1016/\$0921-5093(99)00602-4.

[56] Findley, W. N., Lai, J. S., Onaran, K., and Christensen, R. M. 2010. Creep and Relaxation of Nonlinear Viscoelastic Materials with an Introduction to Linear Viscoelasticity. J Appl Mech. 44(2): 364.

DOI: http://dx.doi.org/10.1115/1.3424077.

[57] Ravi, S., Laha, K., Sakthy, S., Mathew, M. D., and Jayakumar, T. 2014. Design of Creep Machine and Creep 
Specimen Chamber for Carrying Out Creep Tests in Flowing Liquid Sodium. NuCl Eng Des. 267: 1-9.

DOI: http://dx.doi.org/10.1016/j.nucengdes.2013.10.020.

[58] Yen, S. C., and Williamson, F. L. 1990. Accelerated Characterization of Creep Response of an Off-axis Composite Material. Compos Sci Technol. 38(2): 103-118. DOI: http://dx.doi.org/10.1016/0266-3538(90)90001-L.

[59] Grishaber, R. B., Lu, R. H., Farkas, D. M., and Mukherjee, A. K. 1997. A Novel Computer Controlled Constant Stress Lever Arm Creep Testing Machine. Rev Sci Instrum. 68(7): 2812-2817. DOI: http://dx.doi.org/10.1063/1.1148200.

[60] Smith, I. Murray, D. and Day, M. F. 1965. Creep Testing Equipment-design Features and Control. PIME Conf. Proc. 303-307.

[61] Carroll, D. F., Wiederhorn, S. M., and Roberts, D. E. 1989. Technique for Tensile Creep Testing of Ceramics. J Am Ceram Soc. 72(9): 1610-1614.

[62] Østergaard, L., Lange, D. A., Altoubat, S. A., and Stang, H. 2001. Tensile Basic Creep of Early-age Concrete under Constant Load. Cem Concr Res. 31 (12): 1895-1899.

[63] Jorik, S., Lion, A., and Johlitz, M. 2019. Design of the Novel Tensile Creep Experimental Setup, Characterisation and Description of the Long-term Creep Performance of Polycarbonate. Polym Test. 75: 151-158.

[64] Brunbauer, S. 2010. Design and Development of a Testing Machine for Compressive Creep Tests on Polymers at Elevated Temperatures. Institute of Materials Science and Testing of Polymers. Leobon, Austria.

[65] Loni, S. 2013. Experimental and Theoretical Study on the Creep Behavior of GFRP Pultruded Beams. University of Pisa, Pisa, Italy.

[66] European Standards. 1998. Fibre-reinforced Plastic Composites-Determination of Flexural Properties. $\mathrm{Br}$ Stand.

DOI: http://dx.doi.org/10.1520/E0872-82R13.2.

[67] Barr, B. I. G., Lee, M. K., Barragán, B., Dupont, D., Gettu, R., Olesen, J. F., Stang, H., and Vandewalle, L. 2003. Roundrobin Analysis of the RILEM TC 162-TDF Uni-axial Tensile Test: Part 2. Mater Struct Constr. 36(258): 275-280. DOl: http://dx.doi.org/10.1617/13892.

[68] Kusterle, W. 2017. Flexural Creep Tests on Beams-8 Years of Experience with Steel and Synthetic Fibres. RILEM Bookseries. 14: 27-39. DOI: http://dx.doi.org/10.1007/978-94-024-1001-3_3.

[69] Zhao, G., di Prisco, M., and Vandewalle, L. 2015. Experimental Investigation on Uniaxial Tensile Creep Behavior of Cracked Steel Fiber Reinforced Concrete. Mater Struct Constr. 48(10): 3173-3185.
DOI: http://dx.doi.org/10.1617/s1 1527-014-0389-1.

[70] Buratti, N., and Mazzotti, C. 2016. Experimental Tests on the Long-term Behaviour of SFRC and MSFRC in Bending and Direct Tension. Proc. 9th Rilem Int. Symp. Fiber Reinf. Concr.

[71] Buratti, N., and Mazzotti, C. 2016. Uniaxial Tension Tests on Macrosynthetic Fibre Reinforced Concretes. Proc. 9th Rilem Int. Symp. Fiber Reinf. Concr.

[72] Nieuwoudt, P. D., and Boshoff, W. P. 2017. The TimeDependant Pull-out Behaviour of Hooked Steel Fibres in Concrete. Cem and Concr Compos. 79: 133-147.

[73] Daviau-Desnoyers, D., Charron, J.-P., Massicotte, B., Rossi, P., and Tailhan, J.-L. 2017. Creep Behavior of a SFRC Under Service and Ultimate Bending Loads. Creep Behav. Crack. Sect. Fibre Reinf. Concr. Springer. 223-235.

[74] Buratti, N., and Mazzotti, C. 2017. Creep Testing Methodologies and Results Interpretation. RILEM Bookseries.13-24. DOl: http://dx.doi.org/10.1007/978-94-024-1001-3_2.

[75] Babafemi, A. J., and Boshoff, W. P. 2016. Testing and Modelling the Creep of Cracked Macro-Synthetic Fibre Reinforced Concrete (MSFRC) under Flexural Loading. Mater Struct Constr. 49(10): 4389-4400. DOI: http://dx.doi.org/10.1617/s11527-016-0795-7.

[76] Mier, J. G. M. Van, and Vliet, M. R. A. Van. 2002. Uniaxial Tension Test for the Determination of Fracture Parameters of Concrete: State of the Art. Eng Fract Mech. 69: 235247.

[77] Plizzari, G. A., Cangiano, S., and Alleruzzo, S. 1997. The Fatigue Behaviour of Cracked Concrete. Fatigue Fract Eng Mater Struct. 20(8): 1195-1206. DOI: http://dx.doi.org/10.11 1 1/j.1460-2695.1997.tb00323.x.

[78] Li, Z., Li, F., Chang, T. Y. P., and Mai, Y. W. 1998. Uniaxial Tensile Behavior of Concrete Reinforced with Randomly Distributed Short Fibers. ACI Mater J. 95(5): 564-574.

[79] Barragán, B. E., Gettu, R., Martín, M. A., and Zerbino, R. L. 2001. Uni-axial Tension Test for Steel Fibre Reinforced Concrete. Mater Struct. 34(1): 3-6. DOI: http://dx.doi.org/10.1007/BF02482193.

[80] Zerbino, R., Monetti, D. H., and Giaccio, G. 2016. Creep Behaviour of Cracked Steel and Macro-synthetic Fibre Reinforced Concrete. Mater Struct Constr. 49(8): 33973410 DOI: http://dx.doi.org/10.1617/s11527-015-0727-y.

[81] ASTM E21. 2017. Standard Test Methods for Elevated Temperature Tension Tests of Metallic Materials.

[82] ASTM E151. 2011. Standard Test Methods for Tensile, Compressive, and Flexural Creep and Creep- Rupture of Plastics. 